\title{
PERANCANGAN DAN PEMBUATAN ALAT UJI MOTOR LISTRIK INDUKSI AC 3 FASA MENGGUNAKAN DINAMOMETER TALI (ROPE BRAKE DYNAMOMETER)
}

\author{
Asep Rachmat, S.T., M.T., ${ }^{1)}$, Ade Ruhama, S.T. ${ }^{2)}$ \\ Fakultas Teknik, Universitas Majalengka \\ Asep18rachmat75@gmail.com
}

\begin{abstract}
Abstracs -Induction electromotor is one of device convert the energy which is as most used in industrial world, induction electromotor can be used to turn around the pump, blower, konveyor, and other. Any kind Test to electromotor induce of vital importance utilize to support or election guidance for correct electromotor usage, and making a simple dynamometer installation serve the purpose of appliance test the electromotor especially education environment like college. Simple frame and installation pulley electromotor with the braking method use string.
\end{abstract}

Keyword : Induction motor, frame, dynamometer.

\section{PENDAHULUAN}

\subsection{Latar Belakang Mas alah}

Motor listrik induksi AC mempunyai berbagai keunggulan karakteristik dan sangat luas sekali penggunaannya, maka tidak heran bahwa motor listrik AC banyak digunakan di kalangan industri. Oleh karena banyaknya penggunaan motor listrik ini, pengujian terhadap performa motor listrik terutama daya mekanik suatu motor listrik terhadap beban sangat diperlukan guna membantu pelaku industri atau teknisi - teknisi memilih motor listrik yang tepat.

Mengingat hal tersebut pengujian menggunakan alat uji seperti dinamometer perlu dilakukan, namun harga dinamometer fabrikasi sangat mahal harganya, maka pembuatan alat uji motor listrik induksi AC 3 fasa dengan metode brake engine atau dinamometer tali dynamometer rope brake untuk alat uji di labolatorium di tingkat Universitas dengan instalasi sederhana sebagai bahan atau penambah wawasan mahasiswa terhadap karakteristik dan unjuk kerja motor listrik induksi AC 3 fasa sangat diperlukan, yang kelak akan berguna di dalam dunia kerja.

Alat uji motor listrik AC 3 fasa atau dinamometer merupakan alat uji yang bertujuan mengetahui kinerja motor listrik terutama daya mekanik terhadap beban dari motor listrik induksi AC 3 fasa. Alat pengujian motor listrik ini terdiri dari beberapa komponen utama diantara komponen penggerak (alat yang diuji) yaitu motor listrik AC 3 fasa, dan rangka utama. Sedangkan komponen dinamometer tali adalah, puli, saklar, alat ukur pegas beban, ahmmeter, voltmeter, tali dan beban uji.

\subsection{Identifikasi Masalah}

Dari latarbelakang yang telah disampaikan sebelumnya, jelas sekali mengapa perlu dilakukannya pengujian daya mekanik motor listrik induksi yang hanya diketahui spesifikasi daya nominal dari pabrikanya saja yang tertera di nameplate, sementara untuk daya nyata, aktif, dan mekaniknya tidak diketahui.

Pembuatan alat uji yang dilakukan mencakup kegiatan proses produksi (manufacture) menggunakan peralatan atau mesin sederhana, seperti busur las listrik SMAW, mesin bubut, dan lain - lain yang berada di lingkungan kampus.

\subsection{Batasan Masalah}

Untuk lebih terarahnya Tugas Akhir ini penulis membatasipemasalahan yang adadengan beberapa batasan masalah:

1. Analisis pada rangka dilakukan berdasarkan kesetimbangan rangka secara statika, tidak secara terperinci terhadap analisis tegangan pada kolom atau profil.

2. Kekuatan sambungan las hanya dilakukan pada daerah lasan yang mengalami beban terberat.

3. Pembuatan alat uji menggunakan dinamometer rope brake untuk mengukur daya mekanik.

4. Pengujian terhadap variabel beban yang diberikan pada motor listrik induksi AC 3 fasa. 


\subsection{Maksud dan Tujuan Penelitian}

Maksud dan tujuan dari perancangan dan pembuatan alat uji motor listrik induksi AC 3 fasa, dengan tujuan :

1. Alat uji praktikum motor listrik AC 3 fasa di labolatorium Fisika Dasar Fakultas Teknik Universitas Majalengka.

2. Mengetahui performa atau unjuk kerja daya mekanik dari motor listrik induksi AC 3 fasa.

3. Pembuatan instalasi dinamometer tali (dynamometer rope brake) yang sederhana dan layak dipakai sebagai alat uji daya mekanik

4. Mengetahui hasil atau kinerja dari alat uji motor listrik AC 3 fase yang telah diselesaikan pembuatannya dan juga mengetahui perubahan parameter arus, tegangan, putaran dan daya mekanik motor listrik terhadap variabel beban.

\section{LANDASAN TEORI}

\subsection{Motor Induksi Tiga Pasa}

Motor induksi merupakan motor arus bolakbalik yang paling banyak dipakai dalam industri dan rumah tangga. Dikatakan motor induksi karena arus rotor motor ini merupakan arus yang terinduksi sebagai akibat adanya perbedaan antara putaran rotor dengan medan putar yang dihasilkan arus stator.

Motor ini memiliki konstruksi yang kuat, sederhana, dan handal. Disamping itu motor ini juga memiliki efisiensi yang cukup tinggi saat berbeban penuh dan tidak membutuhkan perawatan yang banyak.

\subsection{Kontruksi Motor Induksi Tiga Pasa}

Secara umum motor induksi terdiri dari rotor dan stator. Rotor merupakan bagian yang bergerak, sedangkan stator bagian yang diam. Diantara stator dan rotor terdapat celah udara yang jaraknya sangat kecil.

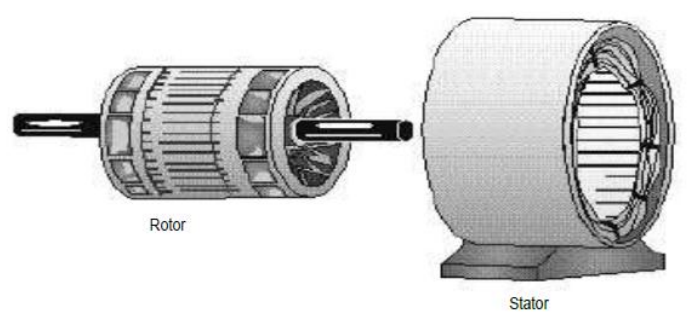

Gambar 2.1. Penampang rotor dan stator motor induksi

Komponen stator adalah bagian terluar dari motor yang merupakan bagian yang diam dan mengalirkan arus phasa. Stator terdiri atas tumpukan laminasi inti yang memiliki alur yang menjadi tempat kumparan dililitkan yang berbentuk silindris. Alur pada tumpukan laminasi inti diisolasi dengan kertas

(Gambar 2.2.(b)). Tiap elemen laminasi inti dibentuk dari lembaran besi (Gambar 2.2 (a)).Tiap lembaran besi tersebut memiliki beberapa alur dan beberapa lubang pengikat untuk menyatukan inti. Tiap kumparan tersebar dalam alur yang disebut belitan phasa dimana untuk motor tiga phasa, belitan tersebut terpisah secara listrik sebesar $120^{\circ}$. Kawat kumparan yang digunakan terbuat dari tembaga yang dilapis dengan isolasi tipis. Kemudian tumpukan inti dan belitan stator diletakkan dalam cangkang silindris (Gambar 2.2.(c)). Berikut ini contoh lempengan laminasi inti, lempengan inti yang telah disatukan, belitan stator yang telah dilekatkan pada cangkang luar untuk motor induksi tiga phasa.
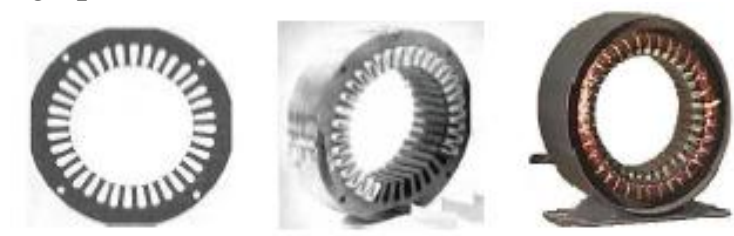

a b $\mathrm{c}$

Gambar 2.2.Menggambarkan komponen stator motor induksi tiga phasa

(a) Lempengan inti

(b) Tumpukan inti dengan kertas isolasi pada beberapa alurnya

(c) Tumpukan inti dan kumparan dalam cangkang stator

Untuk rotor akan dibahas pada bagian berikutnya, yaitu jenis - jenis motor induksi tiga fasa berdasarka jenis rotornya.

\subsection{JENIS MOTOR INDUKSI TIGA FASA}

Ada dua jenis motor induksi tiga fasa berdasarkan rotornya yaitu:

1. motor induksi tiga fasa sangkar tupai (squirrel-cage motor)

2. motor induksi tiga fasa rotor belitan ( wound-rotor motor )

kedua motor ini bekerja pada prinsip yang sama dan mempunyai konstruksi stator yang sama tetapi berbeda dalam konstruksi rotor.

\subsubsection{MOTOR INDUKSI TIGA FASA SANGKAR TUPAI ( SQUIRREL-CAGE MOTOR)}

Penampang motor sangkar tupai memiliki konstruksi yang sederhana. Inti stator pada motor sangkar tupai tiga fasa terbuat dari lapisan - lapisan pelat baja beralur yang didukung dalam rangka stator yang terbuat dari besi tuang atau pelat baja 
yang dipabrikasi. Lilitan - lilitan kumparan stator diletakkan dalam alur stator yang terpisah 120 derajat listrik. Lilitan fasa ini dapat tersambung dalam hubungan delta $(\Delta)$ ataupun bintang ( $\mathrm{Y}$ ).

Rotor jenis rotor sangkar ditunjukkan pada gambar 2.3 di bawah ini.

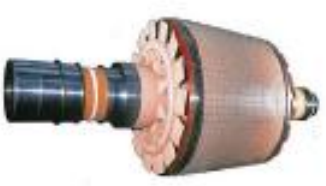

(a)

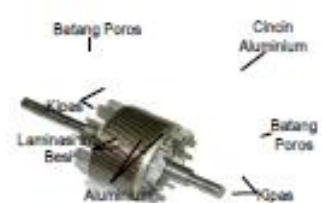

(b) (a)
Gambar 2.3 Rotor sandkar, (a) Tiplal roter smakar, (b) Baginn-bagian rotor sanglar

Batang rotor dan cincin ujung motor sangkar tupai yang lebih kecil adalah coran tembaga atau aluminium dalam satu lempeng pada inti rotor. Dalam motor yang lebih besar, batang rotor tidak dicor melainkan dibenamkan ke dalam alur rotor dan kemudian dilas dengan kuat ke cincin ujung. Batang rotor motor sangkar tupai tidak selalu ditempatkan paralel terhadap poros motor tetapi kerapkali dimiringkan. Hal ini akan menghasilkan torsi yang lebih seragam dan juga mengurangi derau dengung magnetik sewaktu motor sedang berputar.

Pada ujung cincin penutup dilekatkan sirip yang berfungsi sebagai pendingin.Rotor jenis rotor sangkar standar tidak terisolasi, karena batangan membawa arus yang besar pada tegangan rendah. Motor induksi dengan rotor sangkar ditunjukkan pada gambar 2.4.

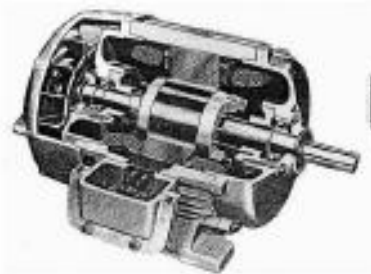

$\mathbf{a}$

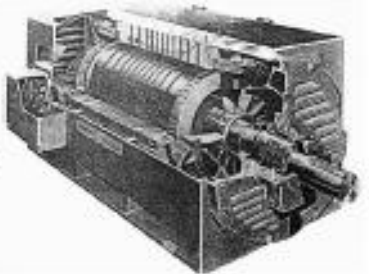

b
Gambar 2.4 (a) Koantrubsi motor indabsi rotor sanglar uluran kecil

(b) Konstrubsi moter indsksi rotor sanglvar ulkuran bosar

\subsubsection{MOTOR INDUKSI TIGA FASA ROTOR BELITAN ( WOUND-ROTOR MOTOR )}

Motor rotor belitan ( motor cincin slip ) berbeda dengan motor sangkar tupai dalam hal konstruksi rotornya. Seperti namanya, rotor dililit dengan lilitan terisolasi serupa dengan lilitan stator.Lilitan fasa rotor dihubungkan secara $\mathrm{Y}$ dan masing masing fasa ujung terbuka yang dikeluarkan ke cincin slip yang terpasang pada poros rotor.Secara skematik dapat dilihat pada gambar 2.5. Dari gambar ini dapat dilihat bahwa cincin slip dan sikat semata - mata merupakan penghubung tahanan kendali variabel luar ke dalam rangkaian rotor.

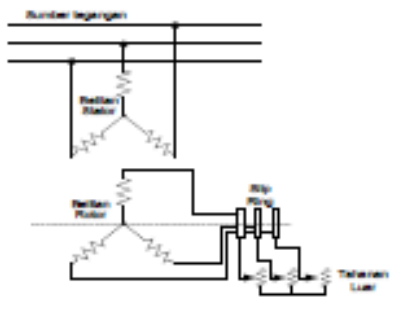

Gambar 2.5 Cicin slip

Pada motor ini, cincin slip yang terhubung ke sebuah tahanan variabel eksternal yang berfunsi membatasi arus pengasutan dan yang bertanggung jawab terhadap pemanasan rotor. Selama pengasutan, penambahan tahanan eksternal pada rangkaian rotor be litan menghasilkan torsi pengasutan yang lebih besar dengan arus pengasutan yang lebih kecil dibanding dengan rotor sangkar.

Konstruksi motor tiga fasa rotor belitan ditunjukkan pada gambar di bawah ini.
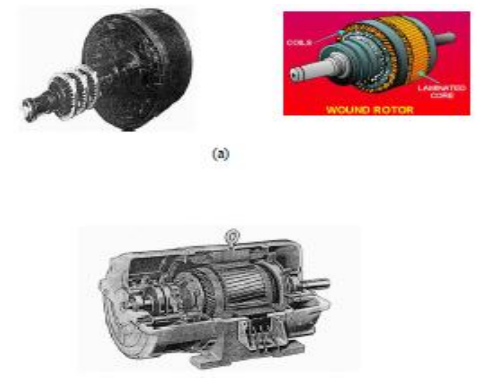

(b)

Gambar 2.6 (a) Rotor belitan (b) Konstruksi motor induksi tiga phasa dengan rotor belitan

\subsection{PRINSIP KERJA MOTOR INDUKSI TIGA FASA}

Pada saat belitan stator diberi tegangan tiga fasa, maka pada stator akan dihasilkan arus tiga fasa, arus ini kemudian akan menghasilkan medan magnet yang berputar dengan kecepatan sinkron. Medan putar akan terinduksi melalui celah udara menghasilkan ggl induksi (ggl lawan) pada belitan fasa stator. Medan putar tersebut juga akan memotong konduktor-konduktor be litan rotor yang diam. Hal ini terjadi karena adanya perbedaan relatif antara kecepatan fluksi yang berputar dengan konduktor rotor yang diam yang disebut juga dengan slip (s). Akibatnya adanya slip maka ggl (gaya gerak listrik) akan terinduksi pada konduktorkonduktor rotor. 


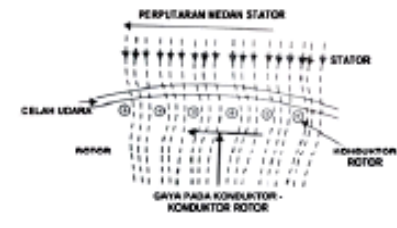

Gambar 2.11. Proses induksi medan putar stator pada kumparan rotor

Karena belitan rotor merupakan rangkaian tertutup, baik melalui cincin ujung (end ring) ataupun tahanan luar, maka arus akan mengalir pada konduktor - konduktor rotor. Karena konduktor konduktor rotor yang mengalirkan arus ditempatkan di dalam daerah medan magnet yang dihasilkan stator maka akan terbentuklah gaya mekanik (gaya lorentz) pada konduktor - konduktor rotor. Hal ini sesuai dengan hukum gaya lorentz (perhatikan gambar 2.9) yaitu bila suatu konduktor yang dialiri arus berada dalam suatu kawasan medan magnet, maka konduktor tersebut akan mendapat gaya elektromagnetik (gaya lorentz) sebesar F= B.i.l.sin $\theta$. Arah dari gaya elektromagnetik tersebut dapat dijelaskan oleh kaidah tangan kanan (right-hand rule). Kaidah tangan kanan menyatakan, jika jari telunjuk menyatakan arah dari vektor arus $i$ dan jari tengah menyatakan arah dari vektor kerapatan fluks $B$, maka ibu jari akan menyatakan arah gaya $F$ yang bekerja pada konduktor tersebut. Gaya $F$ yang dihasilkan pada konduktor - konduktor rotor tersebut akan menghasilkan torsi $(\tau)$. Bila torsi mula yang dihasilkan pada rotor lebih besar daripada torsi beban $(\tau 0>\tau \mathrm{b})$, maka rotor akan berputar searah dengan putaran medan putar stator.

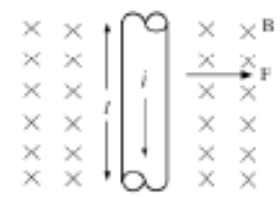

Gambar 2.12. Konduktor berarus dalam ruang medan magnet

Untuk mempe lajari prinsip kerja motor induksi tiga fasa, maka dapat dijabarkan da lam beberapa langkah berikut:

1. Apabila belitan stator dihubungkan dengan sumber tegangan tiga fasa yang setimbang maka akan mengalir arus pada tiap belitan fasa.

2. Arus yang mengalir pada tiap fasa menghasilkan fluks yang berubah-ubah untuk setiap waktu.

3. Resultan dari ketiga fluksi bolak-balik tersebut menghasilkan medan putar yang bergerak dengan kecepatan sinkron ns yang besarnya ditentukan oleh jumlah kutub $\mathrm{p}$ dan frekuensi stator $\mathrm{f}$.
4. Karena kumparan rotor merupakan rangkaian tertutup, maka akan mengalir arus (I2).

5. Adanya arus (I2) di dalam medan magnet akan menimbulkan gaya $(\mathrm{F})$ pada rotor.

6. Gaya (F) akan menghasilkan torsi $(\tau)$. Apabila torsi mula yang dihasilkan lebih besar torsi beban, maka rotor akan berputar dengan kecepatan (nr) yang searah dengan medan putar stator.

7. Pada saat berputar,maka ada perbedaan kecepatan medan putar stator (ns) dengan kecepatan rotor (nr) disebut dengan slip (s)

8. Pada rotor dalam keadaan berputar, besarnya tegangan yang terinduksi pada kumparan rotor akan bervariasi tergantung besarnya slip. Tegangan induksi ini dinyatakan dengan E2S

9. Apabila $\mathrm{ns}=\mathrm{nr}$, maka slip akan bernilai nol. Hal ini akan menyebabkan tidak adanya ggl induksi pada rotor tegangan tidak akan terinduksi dan arus tidak akan mengalir pada kumparan rotor, sehingga tidak akan dihasilkan torsi.

\section{METODOLOGI PENELITIAN}

\subsection{Diagram Alir}

Pada proses penelitian ini ada beberapa tahap yang dilalui hingga dilakukanya proses pembuatan dan proses pengujian alat uji yang dibuat ini. Untuk lebih je lasnya bisa dilihat dalam diagram alir.

\subsubsection{Diagram Alir Penelitian}

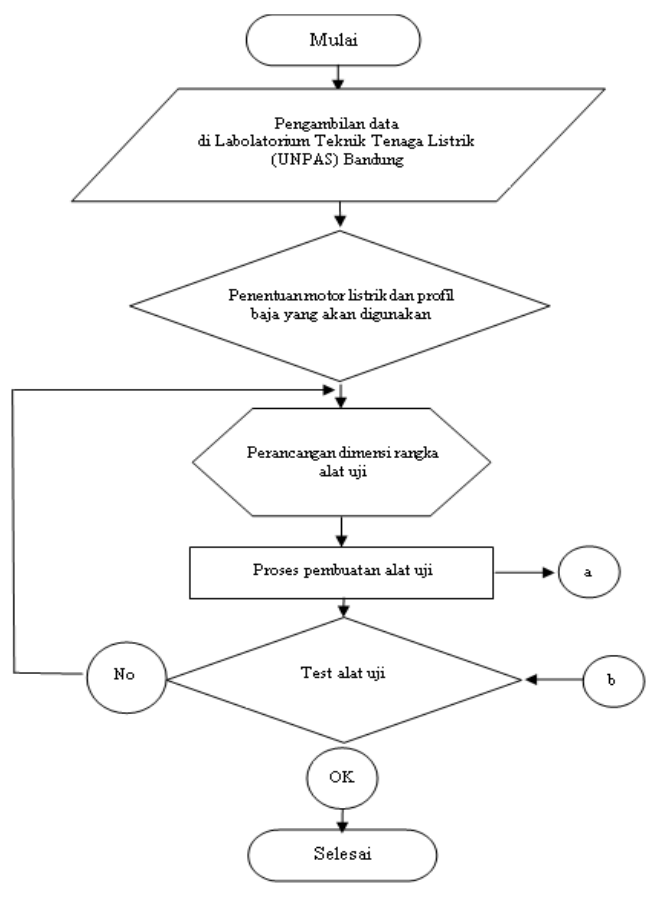




\subsubsection{Diagram Proses Pembuatan}

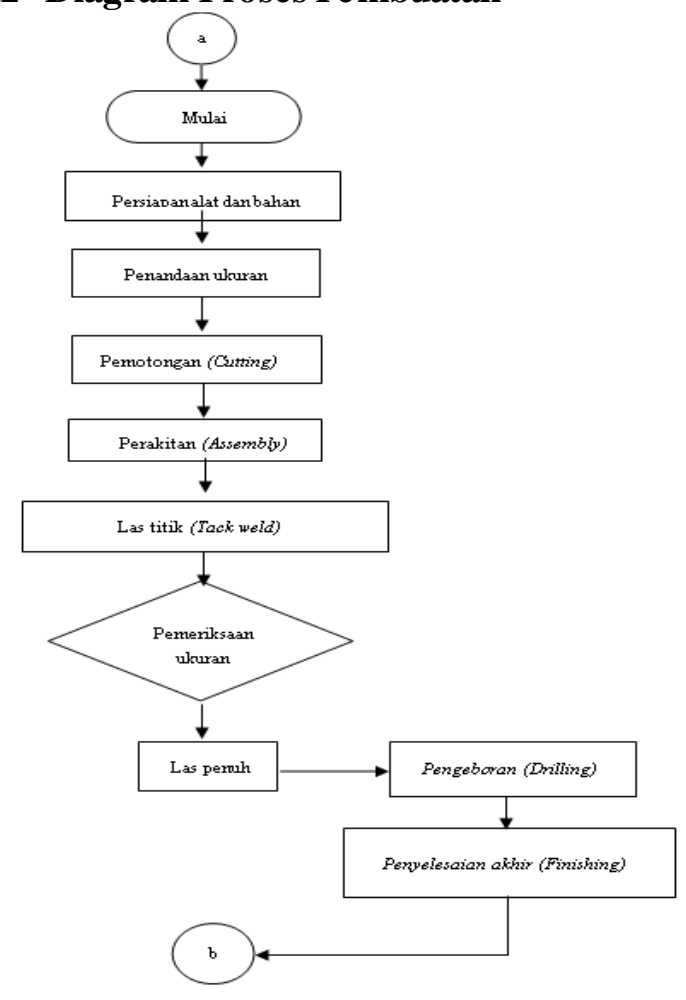

4. ANALISIS PERANCANGAN DAN PEMBUATAN

\subsection{Dimensi dan Pembuatan Gambar Kerja}

Gambar kerja merupakan suatu yang mendasari sebagai acuan dalam pembuatan suatu produk. Dengan adanya gambar kerja, seorang pekerja akan dapat mengidentifikasi dan mengetahui hal-hal yang berkaitan dengan pembuatan alat uji yang akan dibuat. Hal-hal tersebut antara lain :

1. Konstruksi yang akan dibuat.

2. Bahan yang digunakan sesuai ukuran.

3. Urutan proses pengerjaan.

4. Alat yang digunakan.

Desain dari rangka (frames) alat uji yang akan dibuat mempunyai 3 bagian utama dengan fungsinya masing - masing. Bagian - bagian itu diantaranya :

1. Rangka atas yang memiliki fungsi sebagai penopang motor lisrik dan puli.

2. Rangka bawah yang memiliki fungsi sebagai dudukan dari neraca/timbangan.

3. Kaki-kaki rangka yang memiliki fungsi sebagai penopang dari seluruh komponen mesin.

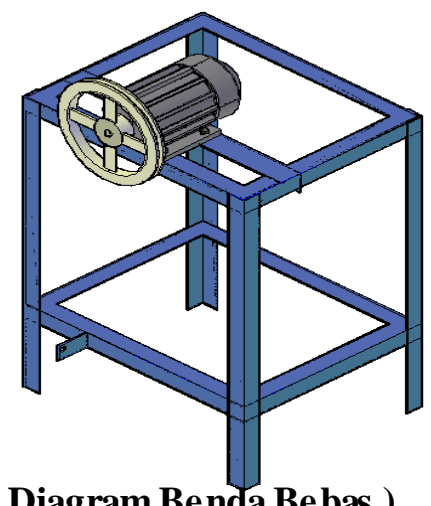

DBB ( Diagram Benda Bebas )
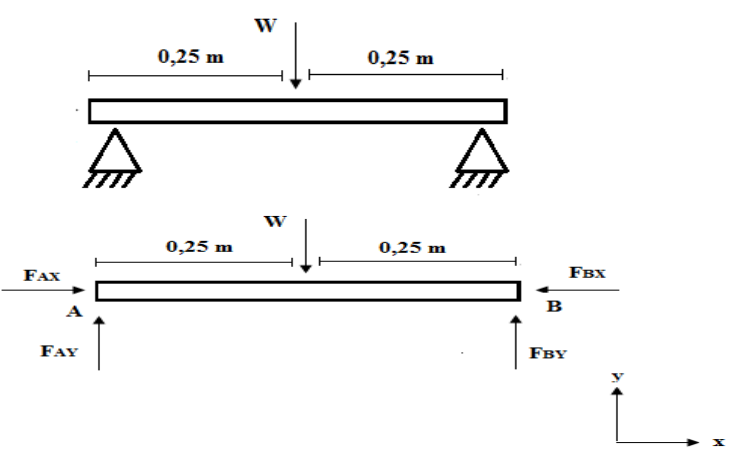

Diagram gaya lintang dan Momen Lentur

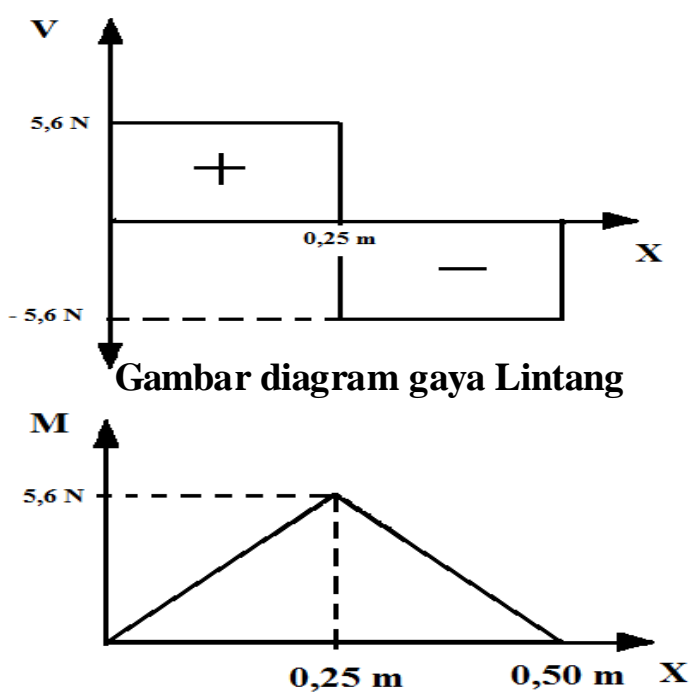

Gambar diagram Momen lentur

\subsection{Beban Dukung Sambungan Las}

Pengelasan yang dilakukan adalah sambungan las double fillet, dan rumus yang digunakan adalah :

$$
P_{i}=\sigma_{\alpha} . \mathrm{A}
$$

Dimana $: P_{i}=$ Beban dukung sambungan las

$$
\sigma_{\alpha}=\text { Tegangan ijin rigi }- \text { rigi las }
$$

$\mathrm{A}=$ Luas penampang las

Pertama kita cari tebal dari lasan dengan rumus :

$$
\begin{aligned}
& a=0,0707 \times s \\
& =0,0707 \times 2 \mathrm{~mm} \\
& =1,41 \mathrm{~mm}
\end{aligned}
$$

Sedangkan panjang lasan telah diketahui : 


$$
\mathrm{L}=2 \times 35 \mathrm{~mm}=70 \mathrm{~mm}
$$

Sehingga, luas lasan dapat dicari

$$
\begin{aligned}
& A=L \times a \\
& =70 \mathrm{~mm} \times 1,41 \mathrm{~mm} \\
& =98,98 \mathrm{~mm}^{2}
\end{aligned}
$$

Tegangan ijin untuk baja St 37 adalah $\sigma_{i}=37$ $\mathrm{N} / \mathrm{mm}^{2}$,

Sedangkan untuk mencari tegangan rigi - rigi las menggunakan rumus :

$$
\sigma_{\alpha}=\frac{\sigma_{i}}{\sqrt{\sin ^{2} \alpha+3 \cos ^{2} \alpha}}
$$

Karena sudut yang dibentuk oleh arah gaya dengan bidang geser las adalah $0^{\circ}$ maka,

$\sigma_{\alpha}=37 \mathrm{~N} / \mathrm{mm}^{2} \times \frac{1}{\sqrt{\operatorname{Sin}^{2} 0^{\circ}+3 \operatorname{Cos}^{2} 0^{\circ}}}$

$=37 \mathrm{~N} / \mathrm{mm}^{2} \times 0,58$

$=21,46 \mathrm{~N} / \mathrm{mm}^{2}$

Setelah didapat luas penampang bidang las dan tegangan ijin rigi - rigi las, masukan kedalam persamaan :

$$
\begin{aligned}
P_{i} & =\sigma_{\alpha} \cdot A \\
& =21,46 \mathrm{~N} / \mathrm{mm}^{2} \times 98,98 \mathrm{~mm}^{2} \\
& =2124,11 \mathrm{~N}
\end{aligned}
$$

Maka sambungan las ini dinyatakan aman untuk menopang beban motor listrik pada kaki rangka sebesar $5,6 \mathrm{~N}$.

\subsection{Tegangan Yang Terjadi Pada Lasan}

Pengelasan yang digunakan las sudut dan tegangan yang terjadi adalah tegangan geser $\left(t_{w}\right)$, maka dapat digunakan persamaan :

$$
t_{w}=\frac{P}{0,707 \cdot s \cdot L}\left(\mathrm{~N} / \mathrm{mm}^{2}\right)
$$

Diketahui :

$$
\begin{aligned}
& P=5,6 \mathrm{~N} \\
& s=2 \mathrm{~mm} \\
& L_{\text {luar }}=2 \times 35 \mathrm{~mm}=70 \mathrm{~mm} \\
& L_{\text {dalam }}=2 \times 35 \mathrm{~mm}=70 \mathrm{~mm}
\end{aligned}
$$

Karena tebal plat pada lasan luar dan dalam sama maka :

$$
\begin{aligned}
& P_{\text {luar }}=P_{\text {dalam }} \\
& F=F_{\text {luar }}+F_{\text {dalam }} \\
& \text { Maka, }
\end{aligned}
$$

$$
=0,028 \mathrm{~N} / \mathrm{mm}^{2}
$$

Masing - masing lasan yang berada di luar maupun di dalam mendapat tegangan sebesar 0,028 $\mathrm{N} / \mathrm{mm}^{2}$, dan tegangan geser maksimum didapat dari jenis elektroda yang digunakan yaitu 248,21 N/mm², sehingga tegangan yang terjadi telah memenuhi syarat, $0,028 \mathrm{~N} / \mathrm{mm}^{2}<248,21 \mathrm{~N} / \mathrm{mm}^{2}$.

\subsection{Proses Pembuatan Rangka Alat Uji}

Dalam membuat a lat uji ini diharapkan hasil yang dikerjakan sesuai dengan yang diinginkan. Rangka alat uji yang dibuat memiliki syarat dan ketentuan yaitu sebagai berikut :

1. Rangka harus dapat menopang motor listrik.

2. Rangka harus tegak atau posisi kaki rangka sama.

3. Semua bagian rangka yang berfungsi sebagai dudukan atau penopang haruslah rata dan datar.

4. Lubang-lubang tempat perakitan komponen lain harus sesuai.

Proses Produksi pembuatan alat yang digunakan adalah :

1. Proses Pemotongan Logam (Cutting)

2. Proses Pengeboran (Drilling)

3. Proses Bubut

4. Proses Pengelasan

5. Finising

6. Asembly 

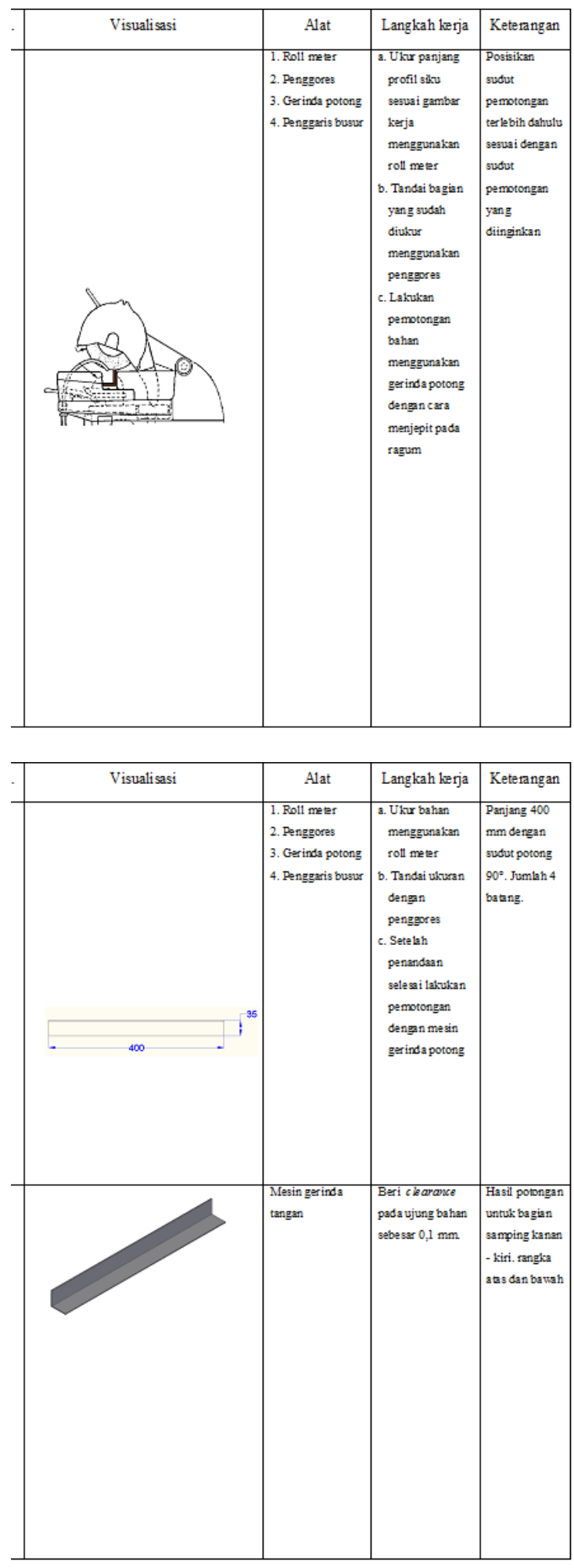

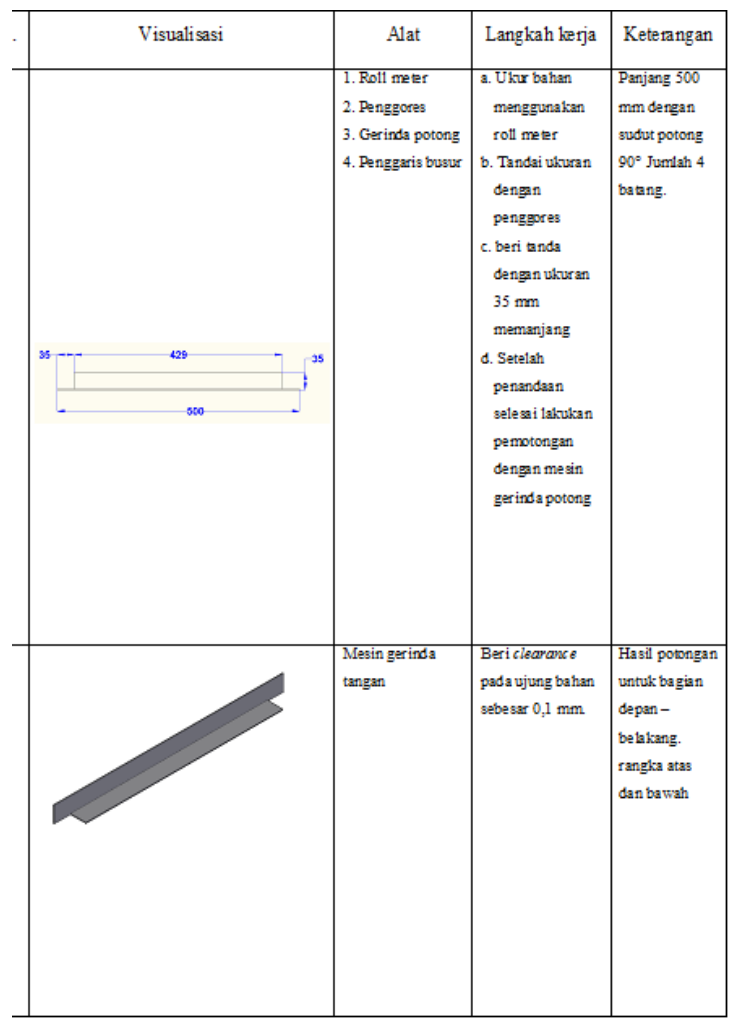

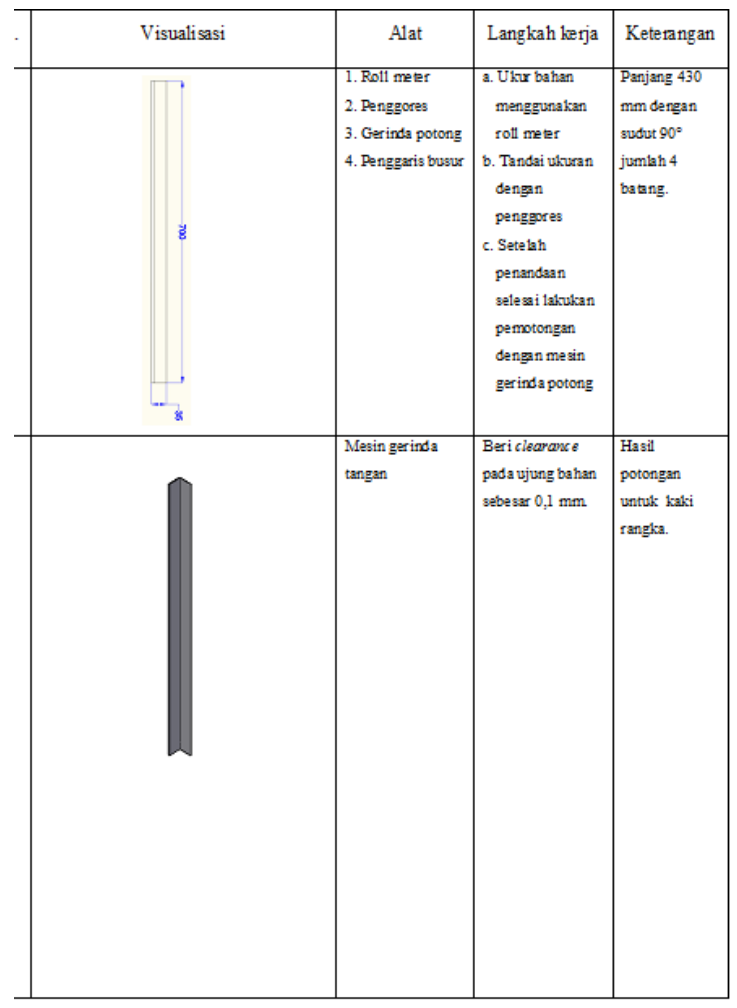



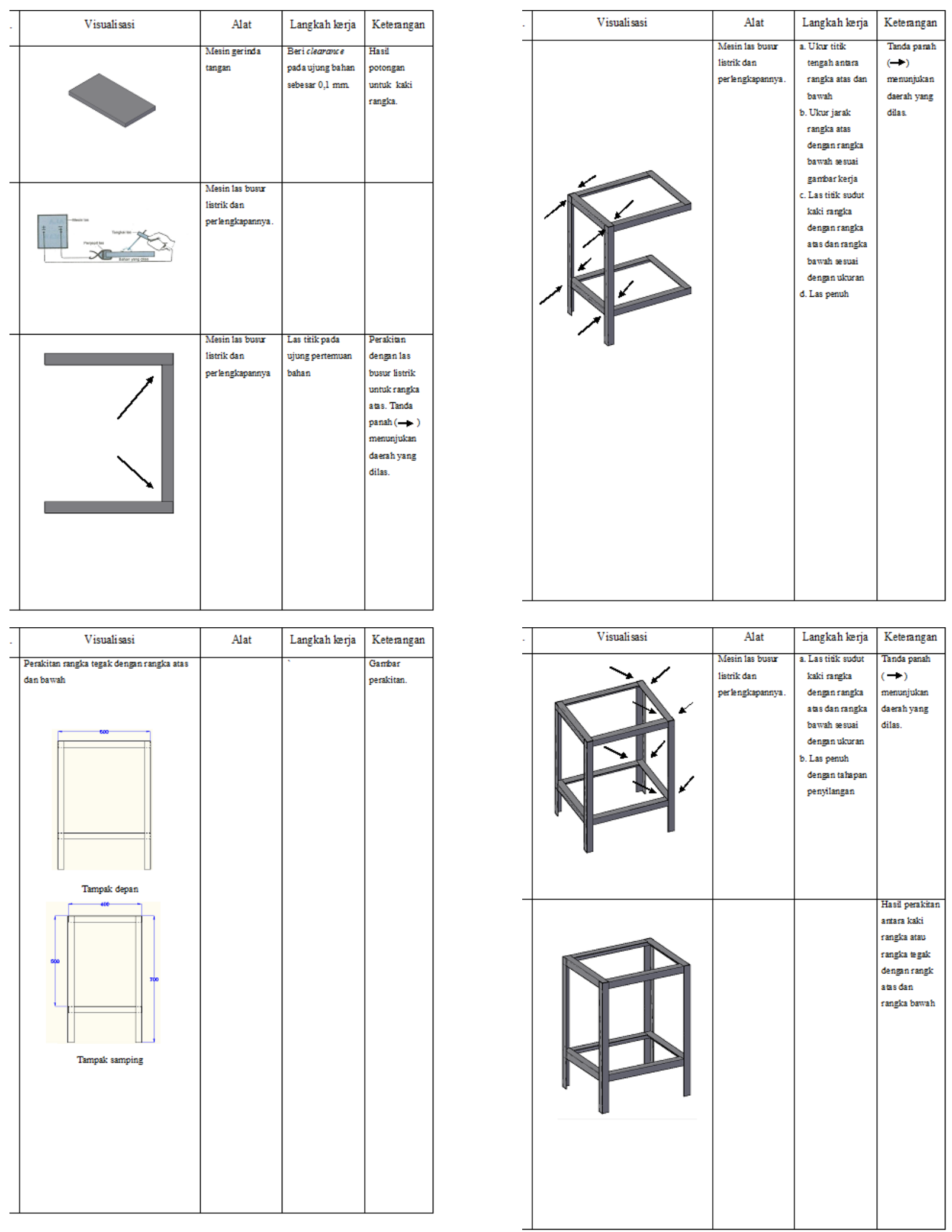

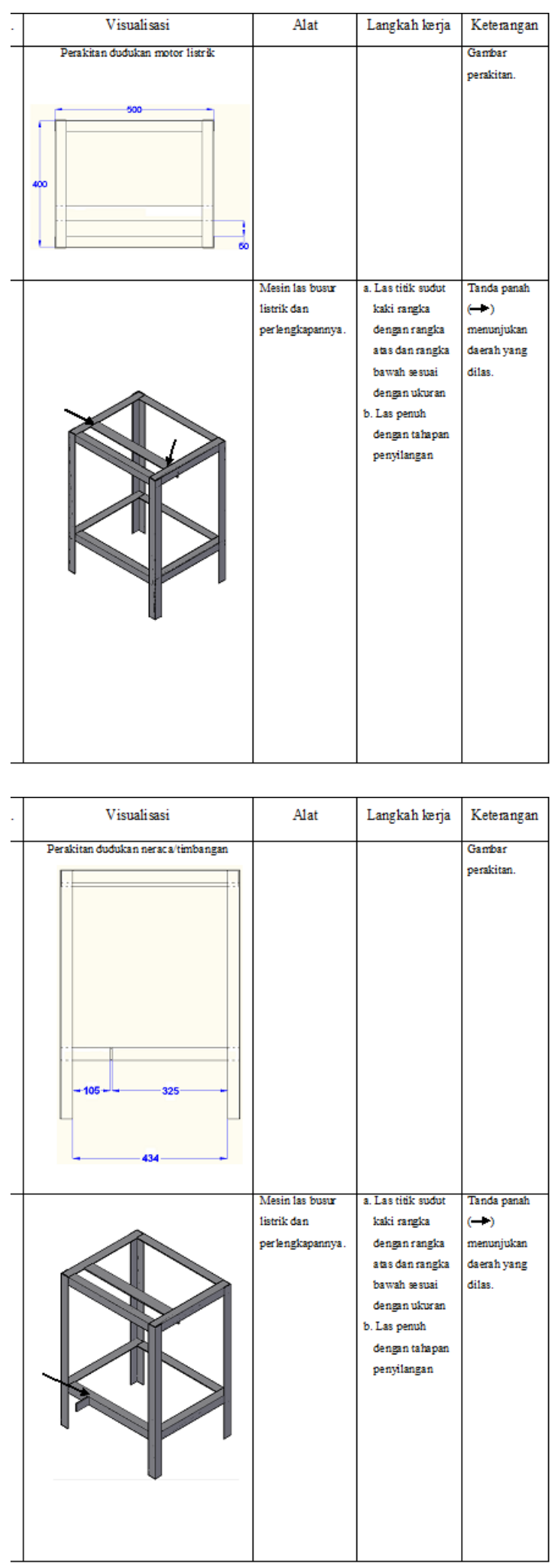
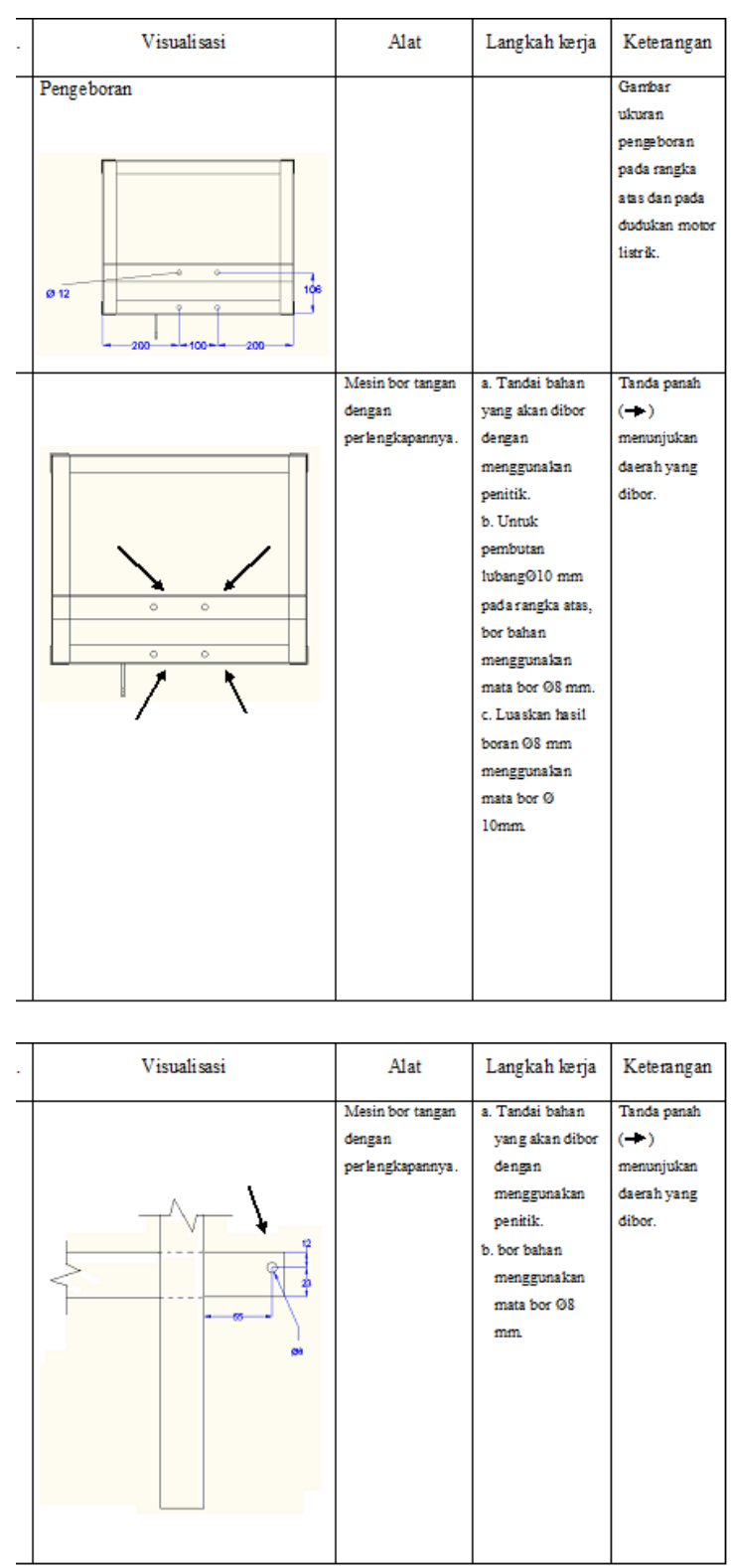

\section{KESIMPULAN DAN SARAN}

\subsection{Kesimpulan}

Dari penelitian dan pembuatan alat uji motor listrik menggunakan instalasi dinamometer tali ini dapat dis impulkan:

1. Perencanaaan dimensi rangka yang telah dibuat telah memenuhi syarat, sehingga pada proses pengujian rangka tidak bergetar.

2. Alat uji ini sangat sederhana namun sangat bermanfaat dalam menguji motor listrik induksi karena dapat mewakili semua ukuran sampai motor induksi berdaya besar. 


\subsection{Saran}

Dari hasil penelitian dan pembuatan yang telah dilakukan, ada beberapa saran yang penulis kemukakan :

1. Peralatan lab yang memadai untuk kegiatan proses produksi atau manufacture di fakultas teknik kedepannya diharapkan bisa dilengkapi, guna menunjang kegiatan mahasiswa.

2. Instalasi pendinginan pada puli sebaiknya disediakan, karena pada pengujian puli akan menjadi panas.

3. Pengembangan dan perbaikan dari alat uji ini sangat diperlukan, diharapkan alat uji ini bisa diolah dan direkayasa kembali oleh mahasiswa - mahasiswa teknik mesin berikutnya. 